\title{
ИСТОРИЯ РАЗВИТИЯ ТУРИСТСКОЙ ИНДУСТРИИ ХАБАРОВСКОГО КРАЯ (1960-Е - 1980-Е ГГ.)
}

\section{DEVELOPMENT OF THE TOURIST INDUSTRY OF THE KHABAROVSK REGION (1960-1980)}

\section{A. Mamonova \\ V. Ivaschenko}

Summary: The article examines the development of railway transport after the adoption of the fundamental documents in the field of tourism in the second half of the twentieth century. The main provisions and tasks set by the management will be considered. The material and technical base of tourism of this period is described and the analysis of the main directions of development of the tourism industry is carried out.

Keywords: tourism, Khabarovsk Territory, railway transport, tourist train, international tourism, Amur cruises.
Мамонова Анастасия Евгеньевна

Тихоокеанский государственный университет

(Хабаровск)

anevk20@mail.ru

Иващенко Вадим Александрович

Старший преподаватель, Тихоокеанский государственный университет (Хабаровск) piter.2013@rambler.ru

Аннотация: В данной статье рассматривается развитие железнодорожных путешествий после принятия основополагающих документов в индустрии туризма второй половины XX века. Исследуются основные положения и задачи, поставленные руководством. Описана материально-техническая база туризма данного периода и проведен анализ основных направлений развития туристской индустрии.

Ключевые слова: туризм, Хабаровский край, железнодорожные путешествия, туристский поезд, международный туризм, круизы по Амуру.
$\mathrm{B}$ 60-е гг. XX в. в СССР начали развиваться транспортные путешествия. С 1960 г. туристские организации профсоюзов впервые стали арендовать поезда у Министерства путей сообщения СССР для организации путешествий по железной дороге [1]. В 1962 г. Президиум ВЦСПС принял Постановление «О дальнейшем развитии туризма». В нем были подведены итоги большой, многолетней работы туристско-экскурсионного управления и добровольных спортивных обществ профсоюзов, а также определены меры, направленные на укрепление материальной базы и расширение массового туризма [2].

Штат каждого туристско-экскурсионного поезда формировался в соответствии с Постановлением президиума ВЦСПС от 4 декабря 1964 г. «О типовых штатах базы экскурсионных бюро советов по туризму» [3]. В указанном документе был предусмотрен следующий штат туристско-экскурсионного поезда при продолжительности более 5 дней: директор, старший инструктор-методист, инструктор, врач, массовик-культорганизатор, аккомпаниатор.

Хабаровскому краю принадлежала ведущая роль на советском Дальнем Востоке в развитии туристских связей с зарубежными странами. Все иностранные туристы и делегации, прибывающие в СССР со стороны бассейна Тихого океана, останавливались в Хабаровске - транзитном железнодорожном центре Дальнего Востока. После открытия международных авиалиний Пхеньян - Хабаровск и Ниигата - Хабаровск в 1973 г. краевой центр стал также и международным аэропортом. Разнообразие и богатство рекреационных ресурсов края, исторические, культурные и хозяйственные объекты, представляющие интерес для иностранцев, высокая степень развития туристской инфраструктуры, включая надежный фонд размещения, - все эти факторы способствовали быстрому развитию иностранного туризма в крае. За период с 1969 по 1985 гг. в Хабаровске побывало свыше 500 тыс. гостей из 80 государств.

В Хабаровском крае функционировало 25 баз отдыха и туризма, 33 спортивно-оздоровительных лагеря, 54 дома рыбака и охотника и 11 пансионатов отдыха. Материальная база туризма укрепилась за счет ввода в эксплуатацию в 1974 г. гостиницы «Турист» в Хабаровске на 500 мест с кинозалом, рестораном, автобазой.

В 1960 г. - первыми пятью поездами воспользовались всего 1650 чел. В 1969 г. было обслужено - 1007,9 тыс. чел., в 1970 г. - 1623,6 тыс. чел., в 1972 г. - 2213,3 тыс. чел., в 1975 г. - 3636,2 тыс. чел. В 1977 г. на туристских железнодорожных маршрутах отдохнуло свыше 4 млн чел. К тому времени курсировало более 2600 туристских поездов [4].

С 13 декабря 1964 г. по воскресеньям от станции Хабаровск-І отправлялся туристский лыжный поезд «Снежинка». После прибытия на Красную Речку он превращался в лыжную базу. Пять часов проводили туристы на лыжных маршрутах среди заснеженных сопок Хехцира. Первыми пассажирами нового маршрута были рабочие и служащие, а также школьники.

Международный туризм был популярен среди ра- 
бочих и служащих. Поездки за границу совершались в 1960-х годах через профсоюзы и бюро международного молодежного туризма «Спутник». Ежегодно около 5 тыс. жителей Хабаровска по линии профсоюзных организаций совершали туристские поездки за границу. Они посещали до 40 стран мира.

Более $80 \%$ туристских связей приходилось на долю социалистических государств. Видное место среди них занимала Народная Республика Болгария. На курортных комплексах Черноморского побережья - «Солнечный берег», «Золотые пески», «Албена» - проводила свой отдых значительная часть туристов. Наиболее любознательные совершали интересные и содержательные поездки по сдвоенным маршрутам: ГДР - ЧССР, ЧССР ВНР, ПНР - ЧССР, СРР - НРБ, СФРЮ - НРБ, СРР - СФРЮ, Индия - Шри-Ланка, Марокко - Испания и др. Большой интерес представляли поездки по КНДР, МНР, Японии и странам Ближнего Востока [5]. Кроме того, хабаровчане получали необходимое лечение на всемирно известных курортах Карлови-Вари и Марианске-Лазне (Чехословакия), Хисар (Болгария), отдыхали на озере Балатон (Венгрия), на побережье Адриатического моря (Югославия), на пляжах знаменитого курорта Варадеро (Куба).

К концу 1960-х г. география зарубежных туров расширилась. Добавились интересные туры «По Дунаю», «По Балтийскому и Северному морям», «По Средиземному морю». В апреле 1966 г. большая группа хабаровчан отправилась на круизном теплоходе «Урицкий» вокруг Японии, посетив города Майдзура, Хиросима, Нагоя, Осака, Токио и Отара на острове Хоккайдо [6].

С марта 1967 г. Хабаровское бюро путешествий и экскурсий организовывало однодневные экскурсии на станцию Волочаевка с посещением музея и встречами с участниками Волочаевского сражения. В период школьных каникул организовывали туристско-экскурсионные поезда «Красная гвоздика» (Хабаровск-Владивосток), «Юность» (Комсомольск-Хабаровск), «Факел» (Хаба-
ровск-Биробиджан). Свыше 500 ребят знакомились с местами революционной, боевой и трудовой славы Спасска, Уссурийска, Владивостока, посещали корабли Тихоокеанского флота.

Большой популярностью пользовались 12- и 14-дневные путешествия по Амуру на комфортабельных пассажирских теплоходах - из Хабаровска в Николаевск, а также из Комсомольска вверх и вниз по реке. Эти речные маршруты привлекали отдыхающих не только со всего Дальнего Востока, но и из Москвы, Ленинграда, Киева и стран Прибалтики.

Шестидневные поездки в Николаевск-на-Амуре проходили на теплоходе «Василий Поярков». Это было особенное путешествие для любителей рыбной ловли. В зависимости от класса каюты такие туры стоили от 65 до 95 рублей в мае и сентябре и от 85 до 115 рублей в летние месяцы. Поездки на теплоходе «Миклухо-Маклай» из Хабаровска в Благовещенск, а затем до Николаевска-наАмуре длились 13 дней. Их преимуществом были экскурсии по памятным историческим местам, знакомство с экономикой и культурой городов Приамурья. В августе 1968 г. появились трехчасовые рейсы «Вечерний Хабаровск», которые первоначально проводились по субботам и сопровождались экскурсоводами с беседами об Амуре. На судне была танцплощадка и работал буфет, играл духовой оркестр. Пароход «Я. Свердлов» в 60-е г. служил плавучей турбазой [7].

Таким образом, в период 1960-х-1980-х гг. на советском Дальнем Востоке наблюдалось массовое развитие туризма. Необходимо отметить, что для этого имелись благоприятные условия. Например, рост благосостояния и культуры народа, увеличение продолжительности ежегодных отпусков, введение пятидневной рабочей недели, а также наличие в крае больших рекреационных ресурсов (зон отдыха). Данные факторы усиливали интерес к туризму как к форме отдыха, включающей познавательный элемент.

\section{ЛИТЕРАТУРА}

1. Пасечный П.С. Туристская работа в трудовом коллективе. - М. : Профиздат. - 1983. - 160 с.

2. Сборник нормативных актов по туристско-экскурсионной работе. - М. : Профиздат. - 1969. - Т. 1. - Ч. 1. - 6 с.

3. Колупанова И.А. Проблемы становления массового туризма в СССР в 1960-1970-е годы (на примере Западной и Восточной Сибири). // Вестник ТГПу (TSPU Bulletin). - 2016. - 9 (174). - 54 c.

4. Абуков, А.Х. Туризм сегодня и завтра. Туристско-экскурсионная работа профсоюзов. - М. : Профиздат. - 1978. - 270 с.

5. Путрик Ю.С. Иностранный туризм В СССР: отражение в научной и учебной литературе. // Современные проблемы сервиса и туризма. - 2016. - №4. - 97 с.

6. Хабаровск шестидесятых: Время надежд. // Ред.-сост. А.П. Врублевский.—Хабаровск: РИА «Юпитер». - 2013. - 176 с.

7. Пичугина Н.А. Организация и проведение туристских железнодорожных маршрутов в Хабаровском крае (60-80-е годы XX в.). // Социальные и гуманитарные науки на Дальнем Востоке. - 2014. - № 2 (42). - 192 с. 